\title{
BLEACHING OF COLOR FIXED COTTONSEED OIL
}

\author{
(Received:11.12.2010)
}

\section{By}

\author{
K. S. M. Hammad, S. A. Hallabo and S. M. Galal
}

Food Technology Department, Faculty of Agriculture, Cairo University, Giza, Egypt

\begin{abstract}
Six varieties of bleaching agents: Commercial, Engelhard and Tonsil bleaching earth, magnesium oxide, aluminum oxide and charcoal were selected to evaluate their abilities on reducing color and gossypol content of color fixed neutralized cottonseed oil. Color of this oil was higher than 50 red units / 20 yellow using Lovibond Tintometer and 1 inch cell and its gossypol content was $200 \mathrm{ppm}$. The bleaching of the color fixed cottonseed oil was carried out by using two methods, conventional method (stirring oil with bleaching earth), and passing the oil on column filled with bleaching adsorbents. The aluminum oxide showed a superior adsorption capacity in reducing color to less than $1.4 \mathrm{red} / 20$ yellow and reducing the gossypol content to $21 \mathrm{ppm}$, by using the column system. The conventional method failed to reduce the color of the treated samples therefore, alkaline pretreatments were conducted. The treatment of color fixed oil with alkaline solution (sodium hydroxide solution $14.5 \mathrm{Be}^{\circ}$ or sodium silicate at $45 \mathrm{Be}^{\mathrm{o}}$ ) followed by conventional Engelhard bleaching earth treatment reduced the color of oil to values lower than $1.4 \mathrm{Red} / 20$ Yellow.
\end{abstract}

Key words: bleaching, color fixation, cottonseed oil and gossypol

\section{INTRODUCTION}

The amount of cottonseed oil produced in Egypt in 2007 reached 46500 tons, while the imported quantity of cottonseed oil represented 5976 tons in 2006 (FAO, 2010).

Cottonseed oil obtained by conventional pressing process or solvent extraction contains gossypol pigments .Bleaching is an important step in the refining of vegetable/animal fats and oils for industrial applications. In edible oil processing, bleaching is responsible for clarified oil that is more stable and also more attractive to the consumer. Clarification is usually performed by an adsorption process which preferentially uses acid-treated clays to remove undesirable oil components .The well known problem of darkening solvent extracted cottonseed oil has been generally known as color fixation. This color problem has been accentuated because of difficulties in removing the fixed pigments from the dark colored oils by the current methods of alkali refining and bleaching. Color fixation occurs when the crude oil or the oilseeds are overheated during processing and it may also occur during their storage prior to processing (Zaher et al.,1991).

Several methods have been developed to remove gossypol pigments from cottonseed oil.
Different chemicals were used in these methods such as ferric chloride (Yatsu et al.,1969), sodium silicate and ethanol amine (Attia et al.,1981) and sodium silicate followed by sodium hydroxide (Taha et al., 1987).

The objectives of this work were to develop several applicable methods to remove pigments, particularly gossypol, from solvent extracted neutralized color fixed cottonseed oil. Color and gossypol content were followed. Besides, oxidative status of oil samples resulted from the succeeded treatments were determined.

\subsection{Materials}

2. MATERIALS AND METHODS

Ten kilograms of solvent extracted alkalirefined cottonseed oil were obtained from ElBadrashin Factory, Cairo Oil and Soap Company, Egypt. Sodium silicate solution $\left(45 \mathrm{Be}^{\circ}\right)\left(\mathrm{SiO}_{2}\right.$ $45.5 \%$ and $\mathrm{Na}_{2} \mathrm{O} 9 \%$ ) was obtained from Ghamra Factory, Cairo Oil and Soap Company, Egypt. Three types of bleaching earth were used in this study: commercial bleaching earth was procured by Nile Valley Vegetable Oil Company, Egypt, Engelhard bleaching earth (0-Basf) grade-F 160 a product of a Chemical Company (U.S.A.)and Tonsil bleaching earth of SudCherie, Mexico were obtained from Cairo Oil and 
Soap Company, Egypt. Besides activated charcoal (obtained from Cairo Oil and Soap Company, Egypt), basic aluminum oxide for analysis (Chromatography grade) (obtained from Hopkin and Williams, Ltd, London) and magnesium oxide (obtained from Hayashi Pure Chemical Ind. Ltd., Osaka, Japan) were also used as bleaching agents. Standards: Gossypol acetic acid obtained from Sigma- Aldrich Company, USA. and Fatty acids of C10,C12,C14,C16,C18,C18:1 ,C18:2,C18:3 and $\mathrm{C} 20$ (purity $>99 \%$ by GLC)were obtained from Koch Light Laboratories , Ltd. England.

\subsection{Methods}

\subsubsection{Physical and chemical properties of cottonseed oil}

Color of refined and bleached cottonseed oil was measured by Lovibond Tintometer using 1 inch cell at 20 yellow, photometric index, refractive index, iodine value, saponification value, soap, unsaponifiable matter, anisidine value, peroxide value, acid value, and total gossypol content were determined according to AOCS official methods (1993). Absorption spectra of $4 \% \mathrm{CCl}_{4}$ solutions of neutralized cottonseed oil (color fixed) and of the bleached oil was determined using Shimadzu spectrophotometer according to Yousef (1998)

\subsubsection{Silicon content}

Silicon content in cottonseed oil was determined before and after silicate treatment by ICP-OC using plasma emission at $288 \mathrm{~nm}$ after ashing according to Masson et al. (2007)

\subsubsection{Gas chromatographic analysis of the fatty} acids

\subsubsection{Extraction of fatty acids}

The fatty acid were extracted from the oil (after saponification and acidification) according to the method described by the AOAC (2000)

\subsubsection{Preparation of fatty acids methyl esters}

The methyl esters of the different fatty acids were prepared using a mixture of methanol: concentrated sulfuric acid at 99:1 v:v and the fatty acids methyl esters were extracted with hexane, according to the method described by Morsi et al (2008).

\subsubsection{Identification of the fatty acids methyl esters by GLC}

The fatty acid methyl esters were analyzed by a Hewlett Packard gas chromatograph apparatus 5890 equipped with a flame ionization detector. The chromatograph apparatus was fitted with FFAP $30 \mathrm{~m} \times 0.32 \mathrm{~mm} \times 0.25 \mathrm{~mm}$ capillary column coated with polyethylene glycol-TPA modified. The column oven temperature was programmed at $7{ }^{\circ} \mathrm{C} / \mathrm{min}$ from $50{ }^{\circ} \mathrm{C}$ to $240{ }^{\circ} \mathrm{C}$, whereas, it was kept for $30 \mathrm{~min}$.Injector and detector temperatures were 260 and $300{ }^{\circ} \mathrm{C}$, respectively. Gas flow rates were $33,30,330, \mathrm{ml} / \mathrm{min}$ for $\mathrm{N}_{2}$, $\mathrm{H}_{2}$ and air ,respectively and the split ratio was 100:1 .Peak identification was performed by at comparison of the relative retention time (RRT) for each peak with those of the standard fatty acids, using the relative retention time of oleic acid as 1.0 . The peak areas and the relative areas of the identified fatty acids were measured using HP Chemstation software .

\subsubsection{Bleaching treatments}

Pretreatment with alkaline solution was conducted before bleaching with conventional method.

\subsubsection{Sodium silicate treatment}

Neutralized color fixed cottonseed oil was treated with 10 and $20 \%$ of sodium silicate (45 $\mathrm{Be}^{\circ}$ ) at $65{ }^{\circ} \mathrm{C}$ for $30 \mathrm{~min}$. using magnetic stirrer. The oil layer was separated by centrifugation at $3000 \mathrm{rpm}$ for $15 \mathrm{~min}$. The treated oil was washed by equal volume of hot water for three times. The washed water was discarded and oil was dried at $105{ }^{\circ} \mathrm{C}$ (Helmy et al.,1994). The treated oil was subjected to bleaching with the most efficient bleaching earth (Engelhard) at (4 and 5\%) at 100 ${ }^{\circ} \mathrm{C}$ with mechanical stirring for $30 \mathrm{~min}$. The oil was recovered by passing through a medium fast filter paper.

\subsubsection{Sodium hydroxide solution treatment}

A $100 \mathrm{ml}$ sample of the neutralized color fixed cottonseed oil was treated with 2.5 and $10 \mathrm{ml}$ sodium hydroxide solution $\left(14.5 \quad \mathrm{Be}^{\mathrm{o}}\right)$. The mixture was stirred mechanically for $30 \mathrm{~min}$. at 65 ${ }^{\circ} \mathrm{C}$. The resulting mixture was centrifuged for 15 min. at 3000 r.p.m (Deacon et al., 1957). The separated oil layer was washed with water till its soap content reached $<300 \mathrm{ppm}$. The oil layer was dried and bleached with the most efficient bleaching earth (Engelhard) at 1.5, 2, 2.5 and 3\% levels and filtered through fast filter paper.

\subsubsection{Bleaching earth treatments}

\subsubsection{Conventional method}

Neutralized color fixed cottonseed oil was bleached with 5\% Engelhard, Tonsil, commercial, Charcoal, $\mathrm{Al}_{2} \mathrm{O}_{3}$ or $\mathrm{MgO}$, at $100^{\circ} \mathrm{C}$ for $30 \mathrm{~min}$. and filtrated through fast filter paper. (Megahad and El-Kinawy, 2001).

\subsubsection{Column system}

Neutralized color fixed cottonseed oil either free from solvent or in the form of miscella (20\% oil in hexane) was bleached by passing over column $(30 \mathrm{~cm} / 1 \mathrm{~cm})$ of $\mathrm{Al}_{2} \mathrm{O}_{3}, \mathrm{MgO}$, or best efficient bleaching earth (Engelhard) only since, using other bleaching agents no oil passed through 
the column. The total quantity of oil that passed through the column with color $<1.4$ red units $/ 20$ yellow using Lovibond Tintometer and 1" cell per 1 part of the adsorbent agent was recorded and this treatment was terminated when color of the treated oil exceeded 1.4 red units/20 yellow.

\subsubsection{Regeneration of adsorbent}

The abused adsorbent (aluminum oxide) was washed several times with acetone (1:1), and then the treated adsorbent was ashed at $550{ }^{\circ} \mathrm{C}$ according to Kuk and Tetlow (2005) before reusing for bleaching.

Bleachability was calculated using the following formula:

Bleachability $=($ Photometric index for color fixed oil-Photometric index for bleached oil)/ Photometric index for color fixed oil) $* 100$ according to Helmy (1985).

\section{RESULTS AND DISCUSSION}

\subsection{Physical and chemical properties of cottonseed oil}

The results in Table (1) show that refractive index at $20 / 20{ }^{\circ} \mathrm{C}$, saponification value, iodine value of the neutralized color fixed cottonseed oil are $1.4692,184 \mathrm{mg} \mathrm{KOH} / \mathrm{g}$ oil and $106 \mathrm{~g} \mathrm{I}_{2} / 100 \mathrm{~g}$ oil, respectively. The same results indicated that acid value, peroxide value, oxidation value (Totox), soap, unsaponifable matter $\%$ are $0.4 \mathrm{mg}$ $\mathrm{KOH} / \mathrm{g}$ oil ,1.87 milliequivalents peroxide $/ \mathrm{kg}$ oil, $, 4.05,626.2 \mathrm{ppm}$ and $2.4 \%$, respectively. These results are in accordance with those of the Egyptian standard for semi refined cottonseed oil No.1837. ( Anon, 2005).

The obtained results in Table (1) show that the total gossypol content and color of the investigated color fixed oil are $200 \mathrm{ppm}$ and more than 50 red at 20 yellow using Lovibond Tintometer and 1 " cell. The fatty acid composition of the investigated oil is in accordance with that of the FAO/WHO food standards (1999). Boki et al. (1992) reported that acid value, iodine value and saponification value of alkali refined cottonseed oil were $0.04 \mathrm{mg} \mathrm{KOH} / \mathrm{g}$ oil,110 g I2 $/ 100 \mathrm{~g}$ and $189.1 \mathrm{mg} \mathrm{KOH} / \mathrm{g}$ oil, respectively. The results in the same Table, (1) demonstrate that the saturated and polyunsaturated fatty acids of the investigated oil reached $29.86 \%$ and $47.11 \%$, respectively. Jones and King (1996) reported that the saturated and polyunsaturated fatty acids of cottonseed oil ranged from $28.8 \%$ to $30 \%$ and from $50.5 \%$ to $52.6 \%$, respectively.
Table (1): Physical and chemical properties of cottonseed oil.

\begin{tabular}{|c|c|}
\hline Tested parameter & $\begin{array}{l}\text { Neutralized color } \\
\text { of Fixed oil }\end{array}$ \\
\hline Refractive index at $20 / 20^{\circ} \mathrm{C}$ & 1.4692 \\
\hline $\begin{array}{l}\text { Saponification value } \\
\text { (mg KOH/gm oil) }\end{array}$ & 184 \\
\hline Iodine value $\mathrm{g} \mathrm{I}_{2} / 100 \mathrm{~g}$ oil & 106 \\
\hline Acid value (mg KOH/gm oil) & 0.4 \\
\hline $\begin{array}{l}\text { Peroxide value( m.equiv. } \\
\text { /1Kg oil) Anisidine value }\end{array}$ & $\begin{array}{ll}1.87 \\
0.318 \\
\end{array}$ \\
\hline Oxidation value (Totox) & 4.05 \\
\hline Soap( ppm) & 626.2 \\
\hline Unsaponifiable matter\%. & 2.4 \\
\hline $\begin{array}{l}\text { Color at } 1 \text { in. cell } 20 \\
\text { yellow*Photometric index }\end{array}$ & $\begin{array}{l}\text { Out of range }>50 \\
\text { red 53.34 }\end{array}$ \\
\hline Gossypol content (ppm) & 200 \\
\hline Silicon content (ppm) & 14 \\
\hline Fatty acids & $\begin{array}{l}\text { Percent by } \\
\text { weight }(\%)\end{array}$ \\
\hline Myristic & 0.79 \\
\hline Palmitic & 25.8 \\
\hline Stearic & 2.83 \\
\hline Arachidic & 0.44 \\
\hline Palmitoleic & 0.8 \\
\hline Oleic & 20.9 \\
\hline Linoleic & 46.76 \\
\hline Linolenic & 0.35 \\
\hline $\begin{array}{l}\text { Total saturated fatty acids } \\
\text { Total unsaturated fatty acids }\end{array}$ & $\begin{array}{l}29.86 \\
68.81 \\
\end{array}$ \\
\hline Un known & 1.33 \\
\hline
\end{tabular}

3.2. Effect of adsorbents on the color and total gossypol content of color fixed cottonseed oil by conventional bleaching

The results in Table (2) indicate that bleaching of refined color fixed cottonseed oil with different bleaching earths at 5\% level did not succeed in reducing either the color of the bleached oil to $<5.5 \mathrm{R} / 20 \mathrm{Y}$ using Lovibond Tintometer (1" cell) a reducing the photometric index to $<12.03$. The highest bleachability $>75 \%$ was recorded for the bleaching earth types: Engelhard and Tonsil. The gossypol content of the Engelhard and Tonsil treated oil samples were 39 and $55 \mathrm{ppm}$, respectively. Comparing the photometric index of color fixed cottonseed oil treated with Engelhard with that of the oil samples treated with other investigated adsorbents indicated that the efficiency of the commercial bleaching earth, aluminum oxide and magnesium oxide in reducing pigments from the oil was $<50 \%$ of that of the Engelhard. The same results showed that the 
efficiency of activated charcoal represented $85 \%$ of that of the Engelhard bleaching earth. These results are in agreement with those of Zaher et al., (1986). who used 3\% Tonsil clay (neutral) to bleach refined cottonseed oil after fixation (crude oil was heated at $60{ }^{\circ} \mathrm{C}$ for one month). Their results showed that the conversion of crude oil pigments to other types of pigments through fixation caused an increase in the bleached oil color, with more marked absorption at $380 \mathrm{~nm}$.

3.3. Effect of adsorbents on the color and gossypol content of color fixed cottonseed oil by column system

Accumulative data in Table (3) obtained from the bleaching process through column show that using $100 \mathrm{~g}$ of each of magnesium oxide, Engelhard bleaching earth and aluminum oxide $\left(\mathrm{AL}_{2} \mathrm{O}_{3}\right)$ is efficient to bleach $170 ; 200$ and $800 \mathrm{~g}$, respectively, of the investigated cottonseed oil to less than 1.4 red $/ 20$ yellow using $1 "$ cell. The same results are obtained by passing $400 \mathrm{~g}$ of oil in the form of miscella $(20: 80)$ over column of $\mathrm{AL}_{2} \mathrm{O}_{3}$. The obtained results indicate that this successful treatment decreased acid value and soap content of cottonseed oil from 0.4 to $0.33 \mathrm{mg}$ $\mathrm{KOH} / \mathrm{g}$ oil and from 626.2 to $179 \mathrm{ppm}$, respectively. Also, the results in the same table prove that the efficiency of the regenerated $\mathrm{AL}_{2} \mathrm{O}_{3}$ is $62 \%$ of that of the fresh $\mathrm{AL}_{2} \mathrm{O}_{3}$.

\subsection{Effect of sodium hydroxide solution (14.5}

$\mathrm{Be}^{\circ}$ ) on the reduction of color and gossypol content of color fixed cottonseed oil

The data in Table (4) reveal that the treated oil with $\mathrm{NaOH}$ solution (14.5\%) at $2.5 \%$ level followed by bleaching with the most efficient bleaching agent (Engelhard bleaching earth ) at $2 \%$ level decreased gossypol content of the oil from $200 \mathrm{ppm}$ to $70.8 \mathrm{ppm}$ and color (red units ) from > 50 to 1.4 .On the other hand, the results show that increasing bleaching earth (Engelhard) level from 2 to 2.5 and $3 \%$ after alkali treatment, $(2.5 \% \mathrm{NaOH})$ caused a clear reduction in color (red units) of the oil to 1.3 and 1.1 and gossypol content to 32.9 and $35.7 \mathrm{ppm}$, respectively .

Increasing bleaching earth level from 2 to $3 \%$ caused a decrease in the photometric index from 2.7 to 2.1 and increased the bleachability from 94.93 to $96.06 \%$. The same results illustrated that increasing $\mathrm{NaOH}(14.5 \%)$ : oil ratio used from 2.5:100 to 10:100 followed by bleaching with lower level of bleaching earth $(1.5 \%)$ caused a remarkable decrease in gossypol content to 43.7 ppm and caused a sharp decrease in color of oil measured by Lovibond Tintometer to less than $0.1 \mathrm{red} / 20$ yellow using 1 inch cell or spectrophotometrically (photometric index) to 0.562 .Though color value of the treated oil $(2.5 \% \mathrm{NaOH}$ followed by bleaching with $2 \%$ Engelhard) was lower than that obtained by $2.5 \% \mathrm{NaOH}$ followed by bleaching with $3 \%$ Engelhard. The total gossypol content of the treated oil resulted from $2.5 \% \mathrm{NaOH}+2 \%$ Engelhard was higher than that of oil resulted from $2.5 \% \mathrm{NaOH}+3 \%$ Engelhard treatment .This contradiction could be due to gossypol derivatives content rather than total gossypol content.

Taha et al. (1987) found that gossypol content and refined oil color (photometric index) of fresh extracted neutralized cottonseed oil (agitation with air ) and that stored for one year before refining (mechanical agitation) were $0 \% ; 62.9$ and $0.1 \%, 25.4$, respectively . Yousef (1998) alkali treated cottonseed oil contained 5\% sodium oleate or $10 \%$ sodium stearate followed by bleaching using Tonsil at $110{ }^{\circ} \mathrm{C}$ for $10 \mathrm{~min}$. He found that gossypol content and color index of 5\% sodium oleate and $10 \%$ sodium stearate oil samples were $0.006 \%, 55.9$ and $0.01 \%$ and 18.3 , respectively.

3.5. Effect of sodium silicate solution $\left(45 \mathrm{Be}^{0}\right)$ and combination of Engelhard and charcoal on reducing color and gossypol content of color fixed cottonseed oil

The results in Table (5) illustrate that treating color fixed cottonseed oil with sodium silicate solution (45 Baume) at 10 and $20 \%$ level for 30 min. at $65^{\circ} \mathrm{C}$ led to a remarkable decrease in its color to 13 and 3.4 red units at 20 yellow using Lovibond Tintometer and 1 inch cell .

Increasing sodium silicate concentration from 10 to $20 \%$ decreased sharply photometric index of the cotton seed oil under investigation from 18.23 to 8.5 and increased bleachability to 84.06 $\%$. However, the color of the silicate treated cottonseed oil was the higher than $1.4 \mathrm{R} / 20 \mathrm{Y}$ as recommended by the Egyptian standard for edible cotton seed oil No. 49-8. (Anon, 1986).

The results in the same table illustrate that treating color fixed cottonseed oil with Engelhard at 4 or $5 \%$ level succeeded in reducing color (red units) of the silicate treated cottonseed oil to 2 and 1, respectively. Addition of charcoal to Engelhard at $10 \%$ level of the Engelhard that was used in the bleaching process decreased color of the silicate treated cottonseed oil to $\leq 1 \mathrm{R} / 20 \mathrm{Y}$ using Lovibond Tintometer and 1 inch cell and decreased the photometric index to $\leq 2.3$. The results showed that the combined treatments of cottonseed oil ( silicate treatment at $10 \%$ level followed by bleaching with 5\% Engelhard $+0.5 \%$ 


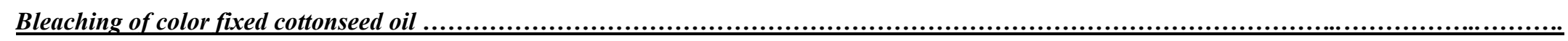

Table (2). The color, Photometric index, Bleachability and gossypol content of color fixed cottonseed oil after different bleaching agents treatments.

\begin{tabular}{|l|c|c|c|c|}
\hline \multicolumn{1}{|c|}{$\begin{array}{c}\text { Type of adsorbent } \\
\text { at 5\% }\end{array}$} & $\begin{array}{c}\text { Color (red units) at 20 } \\
\text { yellow }\end{array}$ & Photometric index & Bleachability & Gossypol (ppm) \\
\hline Bleaching earth (Commercial) & 18.7 & 23.9 & 55.19 & 88 \\
\hline Bleaching earth (Tonsil) & 6.3 & 13.30 & 75.06 & 55 \\
\hline $\begin{array}{l}\text { Bleaching earth } \\
\text { Engelhard) }\end{array}$ & 5.5 & 12.03 & 77.44 \\
\hline Activated Charcoal & 7.9 & 14.11 & 73.54 & 117 \\
\hline Alumina (Al $\mathbf{O}_{3}$ ) & 47.9 & 32.3 & 39.6 & 133 \\
\hline Magnesium oxide & 33.0 & 28.3 & 46.94 & 128 \\
\hline
\end{tabular}

The color and gossypol content of color fixed cottonseed oil was >50 red unit /20 yellow using 1 inch cell and 200ppm, respectively

Table (3). The color and gossypol content of color fixed cottonseed oil after bleached with adsorbents through column system.

\begin{tabular}{|c|c|c|c|c|}
\hline Type of adsorbent & Oil: adsorbent & Photometric index & Bleachability & $\begin{array}{c}\text { Gossypol } \\
(\mathrm{ppm})\end{array}$ \\
\hline Aluminum oxide $\left(\mathrm{AL}_{2} \mathrm{O}_{3}\right)$ & $8: 1$ & .4599 & 99.13 & 21.5 \\
\hline $\begin{array}{l}\text { Aluminum oxide }\left(\mathrm{AL}_{2} \mathrm{O}_{3}\right) \\
\text { oil with hexane }(20: 80)\end{array}$ & 4:1 & .565 & 98.94 & 30 \\
\hline Engelhard bleaching earth & $2: 1$ & .535 & 98.99 & 8.68 \\
\hline Magnesium oxide & $1.7: 1$ & 1.968 & 96.31 & 42 \\
\hline $\mathrm{Al}_{2} \mathrm{O}_{3}$ regenerated first time & $5: 1$ & .463 & 99.13 & 27.1 \\
\hline $\mathrm{Al}_{2} \mathrm{O}_{3}$ regenerated second time & 4:1 & .384 & 99.28 & 30 \\
\hline
\end{tabular}

Color of bleached cottonseed oil for all treatments was $<1.4$ red unit/20yellow using 1 inch cell 
Table (4): The color, gossypol content and loss \% of color fixed cottonseed oil bleached with Engelhard bleaching earth after sodium hydroxide solution $\left(14.5 \mathrm{Be}^{0}\right)$ treatment.

\begin{tabular}{|c|c|c|c|c|c|}
\hline Treatment & $\begin{array}{c}\text { Color (red units) at } 20 \\
\text { yellow }\end{array}$ & Photometric index & Bleach ability & Gossypol (ppm) & Loss $(\%)$ \\
\hline $10 \% \mathrm{NaOH}+1.5 \%$ (Engelhard) & Less than 0.1 & .562 & 98.94 & 43.7 & 16.9 \\
\hline $2.5 \% \mathrm{NaOH}+2 \%$ (Engelhard) & 1.4 & 2.7 & 94.93 & 70.8 & 14.2 \\
\hline $2.5 \% \mathrm{NaOH}+2.5 \%$ (Engelhard) & 1.3 & 2.4 & 95.50 & 32.9 & 14.3 \\
\hline $2.5 \% \mathrm{NaOH}+3 \%$ (Engelhard) & 1.1 & 2.1 & 96.06 & 35.7 & 14.3 \\
\hline
\end{tabular}

Lovibond Color of oil samples treated with $10 \% \mathrm{NaOH}$ or $2.5 \% \mathrm{NaOH}$ was 3.7 red units/20 yellow and 7 red units/20 yellow/ using 1 inch cell , respectively

Table (5): The color and gossypol content of color fixed cottonseed oil bleached with different adsorbents after sodium silicate solution (45 Beo) treatment.

\begin{tabular}{|c|c|c|c|c|}
\hline Treatment & Color (red units) at 20 yellow & Photometric index & Bleach ability & $\begin{array}{l}\text { Gossypol } \\
(\mathbf{p p m})\end{array}$ \\
\hline $10 \%$ Silicate & 13 & 18.23 & 65.82 & 99.5 \\
\hline $10 \%$ silicate $+4 \%($ Engelhard $)$ & 2 & 5.005 & 90.61 & 31.9 \\
\hline $10 \%$ silicate $+4 \%($ Engelhard $)+0.4 \%$ charcoal & $\mathbf{1}$ & 2.3 & 95.68 & 21.9 \\
\hline $10 \%$ silicate $+5 \%($ Engelhard $)+0.5 \%$ charcoal & 0.9 & 2 & 96.25 & 20 \\
\hline $10 \%$ Silicate $+5 \%$ charcoal & 5 & 11.71 & 78.04 & 68.8 \\
\hline $20 \%$ Silicate & 3.4 & 8.5 & 84.06 & 62 \\
\hline Silicate $20 \%+5 \%$ (Engelhard) & 0.6 & 1.077 & 97.98 & 5.7 \\
\hline
\end{tabular}


Table (6): Oxidative status of oil resulted from successful treatments.

\begin{tabular}{|l|c|c|c|}
\hline Type of treatment & $\begin{array}{c}\text { Peroxide value } \\
\text { m.equiv./1Kg oil) }\end{array}$ & Anisidine value & Totox \\
\hline $\mathbf{2 . 5 \%} \mathbf{~ N a O H}+\mathbf{2 \%}$ (Engelhard) & 1.9 & 0.069 & 3.86 \\
\hline Column of $\mathbf{A L}_{\mathbf{2}} \mathbf{O}_{\mathbf{3}}$ & 13.43 & 0.76 & 27.56 \\
\hline $\mathbf{2 0 \%}$ silicate + 5\% (Engelhard) & 15.39 & 0.037 & 30.824 \\
\hline
\end{tabular}

Peroxide value, anisidine value and totox of color fixed oil were 1.87 milliequivalents /Kg oil, 0.318 and 4.05 respectively.

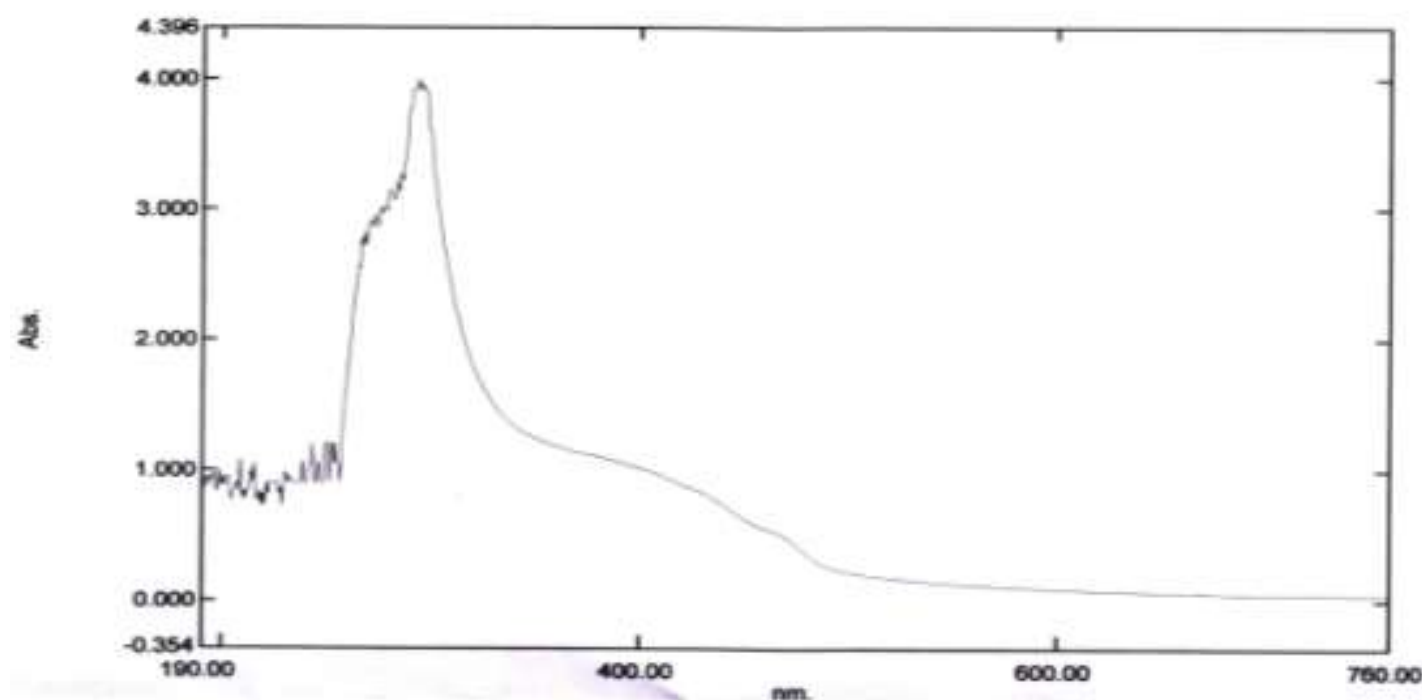

Fig. (1). Absorption spectrum of color fixed cottonseed oil.

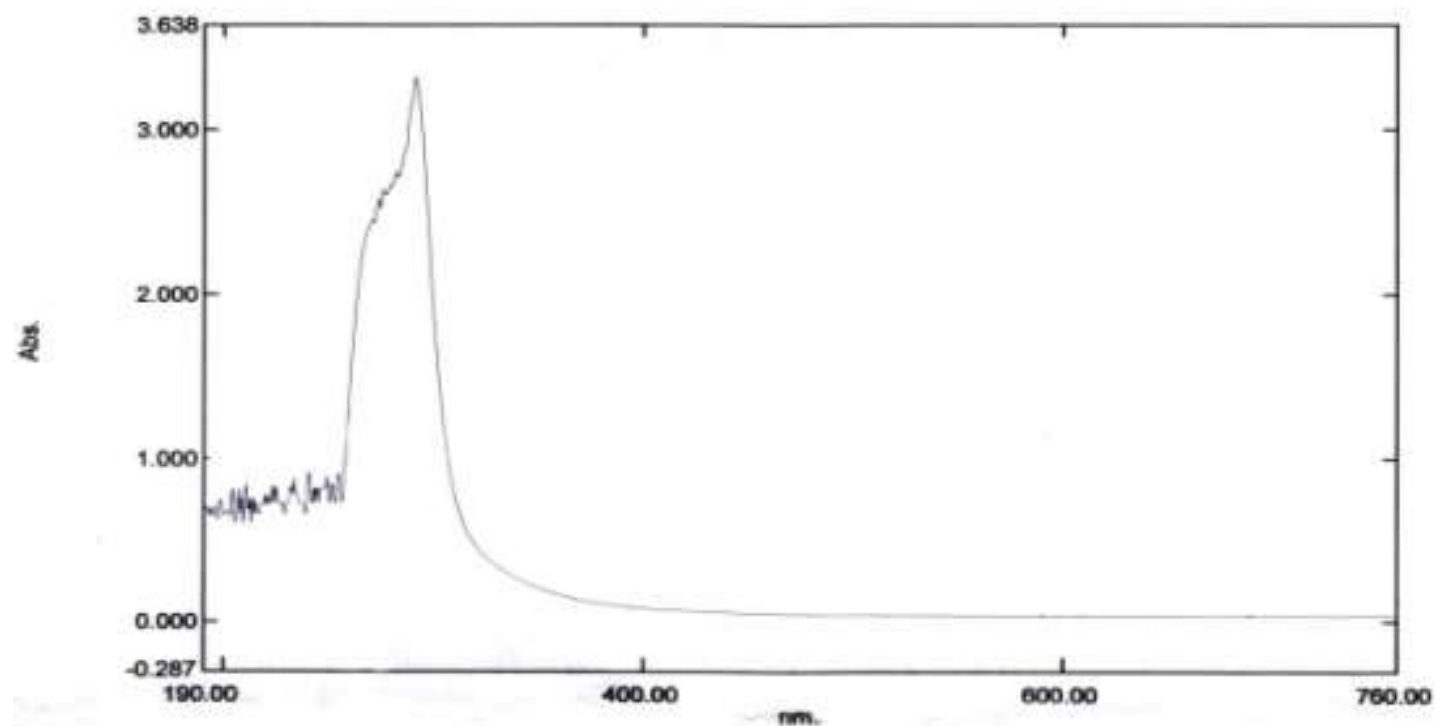

Fig. (2). Absorption spectrum of bleached cottonseed oil ( $\mathrm{Al}_{2} \mathrm{O}_{3}$ treated oil using column system). 
followed by bleaching with 5\% Engelhard $+0.5 \%$ charcoal), (silicate treatment at $10 \%$ level followed by bleaching with $4 \%$ Engelhard), (silicate treatment at $10 \%$ level followed by bleaching with $4 \%$ Engelhard $+0.4 \%$ charcoal) and (silicate treatment at $20 \%$ level followed by bleaching with 5\% Engelhard) increased bleachability to $>90.61 \%$ and decreased gossypol content to $\leq 31.9 \mathrm{ppm}$.

From the results in Tables 3,4 and 5 it could be noticed that the successful treatments in bleaching fixed color cottonseed oil were treating oil with $2.5 \% \mathrm{NaOH}$ followed by bleaching with $2 \%$ (Engelhard), passing tested oil over a column of $\mathrm{AL}_{2} \mathrm{O}_{3}$ at a ratio of 8 parts to 1 part of $\mathrm{AL}_{2} \mathrm{O}_{3}$ and finally treating oil with sodium silicate $\left(45^{0} \mathrm{Be}\right)$ at $20 \%$ level followed by bleaching with $5 \%$ Engelhard. The oxidative status of the oil samples resulted from the successful treatments was evaluated. The obtained results in Table (6) indicate that the best decolorizing treatment that kept the oxidative status of oil from being deteriorated was the $\mathrm{NaOH}$ treatment followed by bleaching with $2 \%$ Engelhard.

Figs. (1 \& 2) illustrate a comparison between the absorption spectra of color fixed cottonseed oil and the bleached oil $\left(\mathrm{Al}_{2} \mathrm{O}_{3}\right.$ treated oil using column system). These figures indicate that bleaching by column system caused a higher reduction in the oil absorption in a wavelength range from 340 to 500 . The pigments which absorb at this range and that could be removed by bleaching. Gossypol, absorption band from 310 to $420 \mathrm{~nm}$; gossyfulvin, an orange colored pigment adsorbs at 440 and gossypurpurin, a purple colored pigment which absorbs from 500 to 560 . These results are in agreement with Zaher et al., (1990).

\section{REFERENCES}

Anon. (1986). Egyptian Organization for Standardization and Quality Control. Egyptian standard for edible cotton seed oil No. 49-8.

Anon. (2005). Egyptian Organization for Standardization and Quality Control. Egyptian standard for semi refined cottonseed oil No.1837.

A. O.A.C. (2000). Official Methods of Analysis of AOAC International $17^{\text {th }}$ edition published by AOAC international, Maryland, U.S.A.

A. O. C. S. (1993). Official and Tentative Methods of the American Oil Chemists' Society, $2^{\text {nd }}$ Ed., Chicago, Illinois, U.S.A.

Attia M., Abbasy M., El-Nockrashy A. S. and
Shoeb Z. E. ( 1981). Cottonseed colour fixed pigments. Part III. Prevention of colour fixation and removal of colour-fixed pigments. Die Nahrung /food, 25(7): 608615.

Boki K., Kubo M., Wada T. and Tamura T. (1992). Bleaching of alkali-refined vegetable oils with clay minerals. JAOCS, 69(3) 232- 236.

Deacon B. D., Harris W. B. and Wamble A.C. (1957). A rapid alkali-wash method of refining cottonseed oil for refined color determination. JAOCS, 34(12) 367-368.

FAO. (2010). Production Year Book. Food and Agriculture Organization (www. FAOSTAT. Org).

FAO/WHO Food Standards. (1999). Standard \#210. Standard for named vegetable oils. Available at http://www.codex-alimentarius.

Helmy H. E. (1985). Factors affecting colour fixation of cottonseed oil. Ph. D. Thesis, Food Sci. Dept., Fac of Agric., Ain Shams Univ.

Helmy H.E., Taha F.S. and Abd El-Motaal E.A. (1994). Treatments of phospholipids to prevent or decrease colour fixation in cottonseed oil. Die Nahrung/Food 38(4) 418-426.

Jones L.A and King C.C. (1996). Cottonseed oil, In: Hui Y.H. (Ed) Bailey`s Industrial Oil and fat Products-5 ${ }^{\text {th }}$ ed .A WileyInterscience Publication, INC., New York p. $159-240$.

Kuk M. S. and Tetlow R. (2005). Gossypol removal by adsorption from cottonseed oil miscella . JAOCS ,82 (12): 905-909.

Masson P., Dauthieu M., Trolard F. and Denaix L. (2007). Application of direct solid analysis of plant samples by electrothermal vaporization-inductively coupled plasma atomic emission spectrometry: Determination of $\mathrm{Cd}$ and $\mathrm{Si}$ for environmental purposes. Spectrochimica Acta Part B (62 ) 224-230

Megahed O.A. and El- Kinawy O.S. (2001) A bleaching earth from Egyptian local deposits . Grasas y Aceites 52 (5) 323-327.

Morsi M. K., Galal S. M. and El-Kholy M. M. (2008). Synthesis and evaluation of sucrose esters. Egyptian Journal Of Nutrition. 23 (3). 1-12

Taha F. S., El-Dewany G. and El-Nockrashy A. S. (1987). Treatment of crude colour fixed oil with sodium silicate. Seifen-Öle-FetteWachse 113 (3) 72-73. 
Yatsu L.Y., Jacks T.J. and Hensarling T. (1969). Use of ferric chloride to decolorize cottonseed oil. JAOCS, 47(2) 73:74.

Yousef E. A. A. (1998). Trials to improve the colour of colour fixed cottonseed oil using sodium oleate and sodium stearate in the absence and presence of azeotropic extract of cottonseed meal .Grasas y Aceites 49 (2) 185-190.

Zaher F. A., Aly S. M. and Mohammed S. S. (1991). The effect of the atmospheric oxygen on the conversion rate of gossypol pigment to unrefinable form. Egypt J. Food Sci., 19 (3) 366-374.

Zaher F. A., El-Shami S.M. and El-Mallah M. H. (1986). Vegetable oil quality as affected by overheat treatment of crude oil prior to refining .Seifen-Öle-Fette-Wachse .112 (7) 223-225.

Zaher F. A., Hawash S. and El Diwani G. (1990). Semi-pilot study on the refining of cottonseed oil in miscella. Grasas. $y$ Aceites 41(2) 193-143.

\section{تبيض زيت بذرة القطن ذو اللون الثابت \\ كريمة سعيد محل حماد - سعد احمد حلابو - سامى حمل جلال \\ قسم تكنولوجيا الاغذية ـ كلية الزر اعة-جامعة القاهرة - الجيزة - مصر}

تم اختيار ستة أنو اع من تر اب التبيض هى : تراب تبيض تجارى ، أنجلهارد ، تونسل ، أكسيد ماغنسيوم ، اكسيد

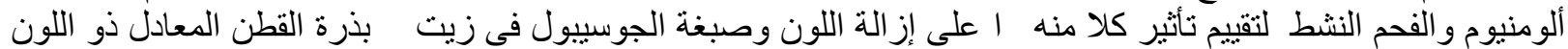

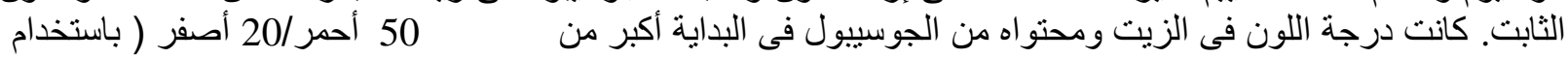

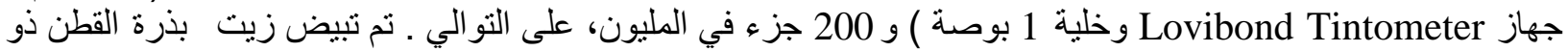

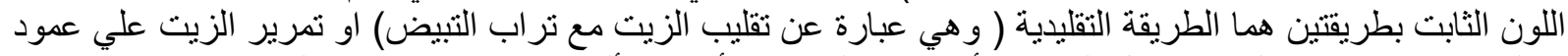

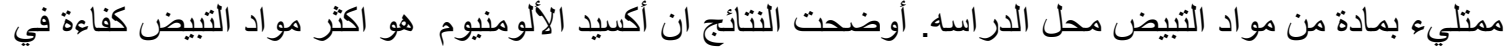

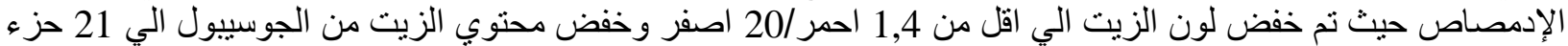

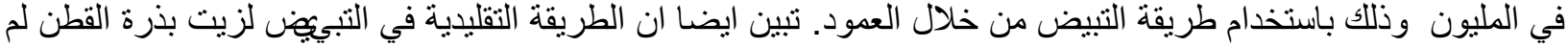
تؤد الغرض المطلوب من حيث خفض اللون ومحتوي الجوسيبول في الزيت ولهذا السبب نم ادخال معاملات اولية بمو اد قلوية علي الزيت مثل (محلول هيدروكسيد صوديوم 14,5بومية او سليكات صوديوم 45 بومية ) يتبعها التبيض بالطريقة التقليدية

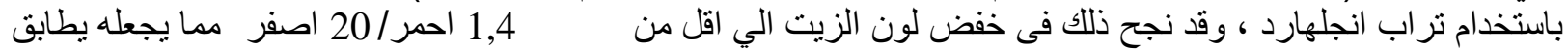

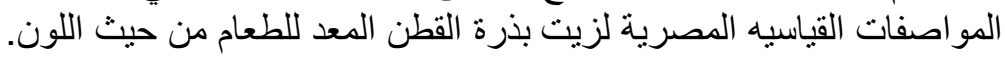

